\title{
GREEN SYNTHESIS OF SILVER NANOPARTICLES USING SAGE AND THEIR ANTIBACTERIAL EFFECT ON GRAM-POSITIVE AND GRAM-NEGATIVE BACTERIA
}

\author{
1,2,3 Karel SEHNAL, ${ }^{1,2}$ Dagmar UHLIROVA, 1,2Martina STANKOVA, 1,2Michaela VSETICKOVA, \\ 1,2Zuzana TOTHOVA, ${ }^{1,2,5}$ Bozena HOSNEDLOVA, ${ }^{6}$ Marta KEPINSKA, ${ }^{1,3}$ Branislav RUTTKAY- \\ NEDECKÝ, "4Duong Ngonc BACH, ${ }^{1}$ Jiri SOCHOR, ${ }^{6}$ Halina MILNEROWICZ, ${ }^{4}$ Hoai Viet NGUYEN, \\ 1,2,3,5,6Rene KIZEK
}

${ }^{1}$ Department of Viticulture and Enology, Faculty of Horticulture, Mendel University in Brno, Lednice, Czech Republic, EU, karelsehnal15@gmail.com

${ }^{2}$ Department of Research and Development, Prevention Medicals s.r.o., Studenka-Butovice, Czech Republic, EU, uhlirova@preventionmedicals.cz

${ }^{3}$ Department of Human Pharmacology and Toxicology, University of Veterinary and Pharmaceutical Sciences Brno, Brno, Czech Republic, EU, kizek@sci.muni.cz

${ }^{4}$ Research Center for Environmental Monitoring and Modeling, VNU University of Science, 332 Nguyen Trai street, Thanh Xuan district, Hanoi, Vietnam, nguyenviethoai@hus.edu.vn

${ }^{5}$ Department of Food and Feed Safety, Veterinary Research Institute, Brno, Czech Republic, EU

${ }^{6}$ Department of Biomedical and Environmental Analyses, Faculty of Pharmacy with Division of Laboratory

Diagnostics, Wroclaw Medical University, Wroclaw, Poland, EU, zalewska.m@gmail.com

https://doi.org/10.37904/nanocon.2019.8573

\begin{abstract}
In this work, we focused on the green synthesis of silver nanoparticles (AgNPs). In the green synthesis, plant extracts are used as reducing agents. AgNPs contain surface-bound biomolecules from the used plant extract. We used an aqueous extract from sage (Salvia officinalis). This plant is known for its high content of secondary metabolites with excellent antibacterial activity. Antibacterial activity of AgNPs prepared by green synthesis was investigated. Gram-positive bacteria Staphylococcus aureus and Gram-negative bacteria Escherichia coli were selected for testing. Methods such as agar diffusion assay and inhibition of bacterial growth curves were used. Minimum inhibitory concentrations $\left(\mathrm{MIC}_{E \text {. coli }}=250 \mu \mathrm{g} / \mathrm{mL} ; \mathrm{MIC}_{\text {s. aureus }}=50 \mu \mathrm{g} / \mathrm{mL}\right.$ ) were determined. The radiuses of inhibition zones were about $1.5 \mathrm{~cm}$ in both bacterial strains. AgNPs prepared by this method can play an important role in dealing with the problem of bacterial resistance. Bacteria develop resistance not only to typical antibiotics. Bacterial cells are also able to eliminate the effect of AgNPs. By modifying their surface with antibacterial molecules, resistance can be effectively combatted.
\end{abstract}

Keywords: Green synthesis, silver nanoparticles, antibacterial activity, minimum inhibitory concentration

\section{INTRODUCTION}

Sage (Salvia officinalis) is used in traditional medicine for its antibacterial effects [1,2]. The antitumor activity of sage was also reported [3]. This plant is found in the temperate, subtropical, and tropical areas [4]. Sage is known for its content substances, especially phenolic compounds with the highest content of caffeic acid, vanillic acid, ferulic acid, luteolin, apigenin, quercetin, rosmarinic acid and their derivatives [5-7]. The main secondary metabolites playing an important role in antibacterial activity are primarily phenolic substances, such as salviol and thujone [8-11] (Figure 1). 


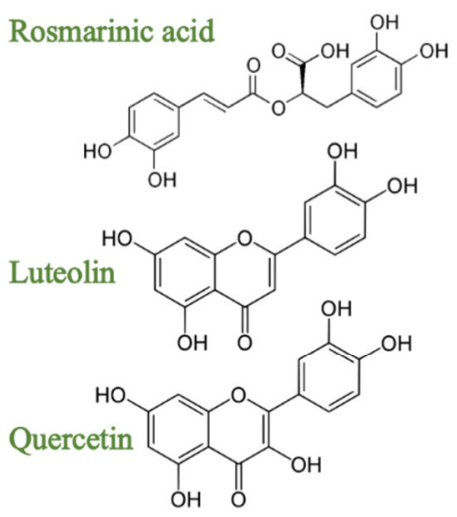<smiles>COc1cc(/C=C/C(=O)O)ccc1O</smiles>

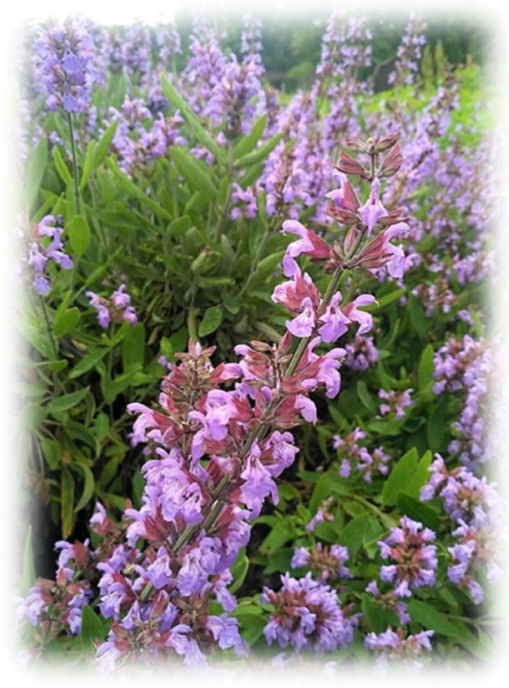

Figure 1 The most common secondary metabolites of sage (Salvia officinalis)

The antibacterial effect of silver nanoparticles (AgNPs) has been well known for more than 10 years [12]. AgNPs disintegrate into silver ions upon $\mathrm{pH}$ change, producing free oxygen radicals and inhibiting cell growth (Figure 2).

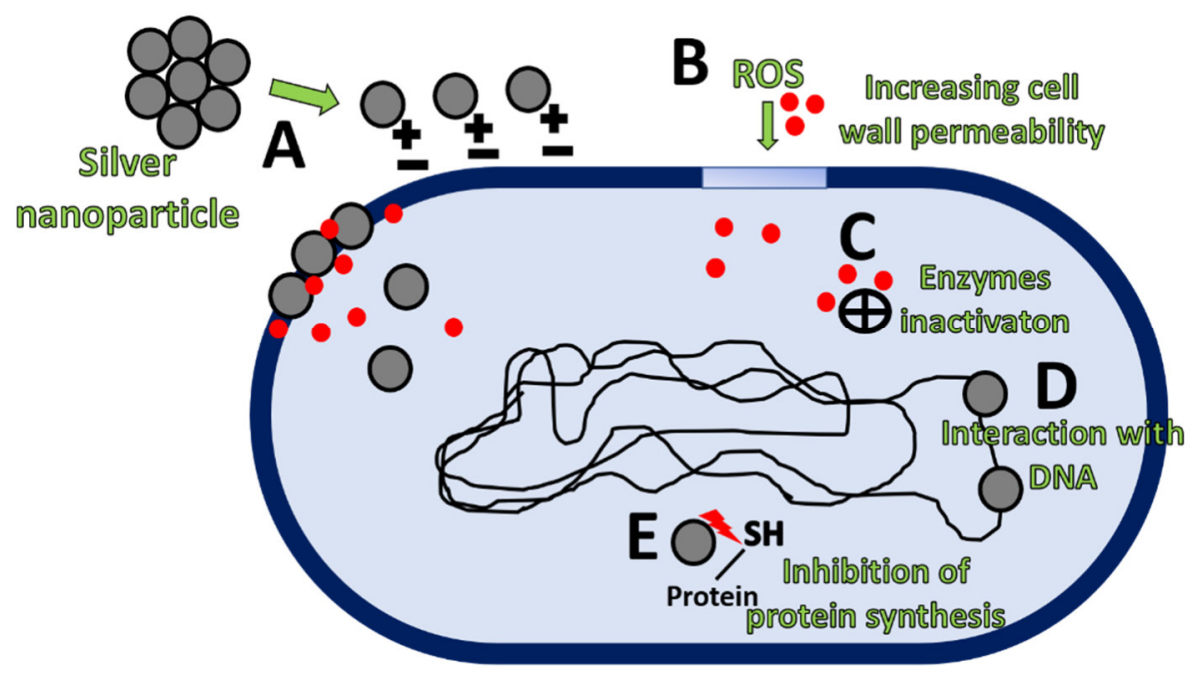

Figure $2(\mathrm{~A})$ The antibacterial activity of the silver nanoparticles is based on their disintegration into silver ions, which bind into the cell wall and produce oxygen free radicals. (B) Reactive oxygen species (ROS) increase both cell wall and membrane permeability, causing immediate cell death. (C) In addition, they inactivate the enzymes, thereby inhibiting the many chemical reactions required for the bacterial life. (D) Silver ions interact with DNA to which they bind and damage transcription and translation. (E) They act on $\mathrm{SH}$ groups of proteins and inhibit their synthesis.

In the procedure of green synthesis aqueous extract of sage was used to replace classical chemical reducing agents. When using green synthesis, the antibacterial activity of AgNPs is supported by bound antibacterial molecules found in the plant extract. Recently, there have been discussions about the possibility of modifying 
AgNPs with molecules of antibiotics and other antibacterial agents or various cytostatics to improve the chemotherapeutic effect.

World population is facing problems associated with resistant bacteria. According to the European Center for Disease Prevention and Control (ECDC), these bacteria cause 33,000 deaths in Europe annually. Our work is focused on investigation of antibacterial activity of AgNPs prepared using the so-called green synthesis process. Because of the bonded biomolecules on the surface of AgNPs prepared by this synthesis, AgNPs can be used to treat infections caused by antibiotic resistant bacteria.

\section{MATERIAL AND METHODS}

\section{AgNPs green synthesis and characterization}

An aqueous extract of $S$. officinalis was used for green synthesis. The dried plant was purchased from Valdemar Grešík - Natura s.r.o. The plant was homogenized to fine dust by grinding. An aqueous extract $(10 \mathrm{~g} / 100 \mathrm{~mL})$ was prepared at $60{ }^{\circ} \mathrm{C}$. The mixture was stirred on a magnetic stirrer for 1 hour. The mixture was further centrifuged $(14,000 \mathrm{~g}, 15 \mathrm{~min})$ and filtered. The obtained extract was mixed with $0.1 \mathrm{M} \mathrm{AgNO}_{3}$ in $1: 1$ ratio. A visible color change occurred during the reaction ( $24 \mathrm{hrs})$ with stirring. After the reaction, the mixture was stirred with methanol for 1 hour in 1:1 ratio, centrifuged (30 min, 14,000 g), the supernatant was pipetted off and the pellet was dried $\left(60^{\circ} \mathrm{C}, 24 \mathrm{hrs}\right)$. An aqueous dispersion of AgNPs was prepared by sonication (40 min) with which was used for further experiments.

AgNPs were characterized by spectral analysis (Single-beam spectrophotometer VWR, USA) and by hydrodynamic light scattering (Zetasizer Nano ZS ZEN3600 from Malvern Instruments, UK). The shape and size of nanoparticles was characterized by TEM and SEM. Moreover, the surface of AgNPs was characterized by obtaining XRD spectrum. Total protein concentration was measured using two methods (biuret and pyrogallol red-molybdate) using an BS-300 chemical analyzer (Mindray, China). Aluminium chloride spectrophotometric method was used to measure the concetration of total flavonoids. Antioxidant activity (ABTS, DPPH methods) was measured by BS-300 chemical analyzer (Mindray, China). VIS absorption spectrum was obtained by using spectrophotometer (UV 3100 PC).

\section{Agar diffusion assay}

$10 \mathrm{~mL}$ of Luria-Bertani (LB) medium (tryptone, yeast extract, $\mathrm{NaCl}$, agar) was applied to a Petri dish. The bacterial suspension in LB medium was diluted to $\mathrm{OD}=0.01 .50 \mu \mathrm{L}$ of the diluted suspension was spread on a Petri dish and $10 \mu \mathrm{L}$ of AgNPs $(\mathrm{c}=10 ; 5 ; 2.5 ; 1.25 \mathrm{mg} / \mathrm{mL})$ was applied. The resulting inhibition zones were observed.

\section{Measurement of growth curves}

Infinite F50 (TECAN, Switzerland) was used to measure growth curves. $248 \mu \mathrm{L}$ of LB medium, $2 \mu \mathrm{L}$ of bacterial suspension (OD $=0.01)$ and $10 \mu \mathrm{L}$ of AgNPs $(\mathrm{c}=10,9,8,7,6,5,4,3,2,1 \mathrm{mg} / \mathrm{mL})$ were pipetted into the microtiter plate. Growth curves were measured for $12 \mathrm{~h}$. They were evaluated in the Qinslab system (Prevention Medicals, s.r.o). Minimal inhibitory concentrations were calculated using Probit analysis.

\section{RESULTS AND DISCUSSION}

Various shapes and sizes of AgNPs in the prepared dispersion were detected by gel electrophoresis and gradient centrifugation. Different nanoparticle shape and size affect antibacterial activity [13]. In AgNPs, total protein concentration was determined using both the biuret $(54.9 \mathrm{mg} / \mathrm{L})$ and pyrogallol red-molybdate (22 $\mathrm{mg} / \mathrm{L}$ ), methods, and the content of flavonoids was found using the aluminium chloride spectrophotometric method ( $25 \mathrm{mg} / \mathrm{L})$. Antioxidant activity of AgNPs was determined by ABTS (90.2 mg GAE/L) and DPPH 
methods (953 mg GAE/L). The hydrodynamic size of AgNPs was about $35 \mathrm{~nm}$. Absorption spectra reached a maximum at $450 \mathrm{~nm}$. AgNPs inhibition zones obtained using agar diffusion assay at AgNPs concentrations used $10,5,2.5$, and $1.25 \mathrm{mg} / \mathrm{mL}$ showed radiuses in $S$. aureus culture - 1.6, 1.5, 1.4, and $1.2 \mathrm{~cm}$, respectively, and in $E$. coli culture $-1.5,1.2,1.2$, and $1.3 \mathrm{~cm}$, respectively. No significant difference in the effect of AgNPs on $\mathrm{G}^{+}$or $\mathrm{G}^{-}$bacteria was observed. We believe that due to the relatively large size of AgNPs, their ability to diffuse through the medium is reduced. (Figure 3A). Minimal inhibitory concentrations were determined using Probit analysis: $\left(\mathrm{MIC}_{E \text {. coli }}=250 \mu \mathrm{g} / \mathrm{mL} ; \mathrm{MIC}_{S \text {. aureus }}=50 \mu \mathrm{g} / \mathrm{mL}\right)$. Measurement of growth curves showed a significantly better antibacterial effect on Gram-positive bacteria. While monitoring the inhibition of $S$. aureus growth, the shift at the beginning of the kinetic phase of the growth curve with increasing AgNPs concentration was very well seen. In E. coli, this shift was not observed using the same concentrations as in $S$. aureus. We assume an increased amount of bound silver ions into the wider cell wall of $\mathrm{G}^{+}$bacteria. More ions produce more ROS and thus more effectively inhibit bacterial cell growth (Figure 3B).

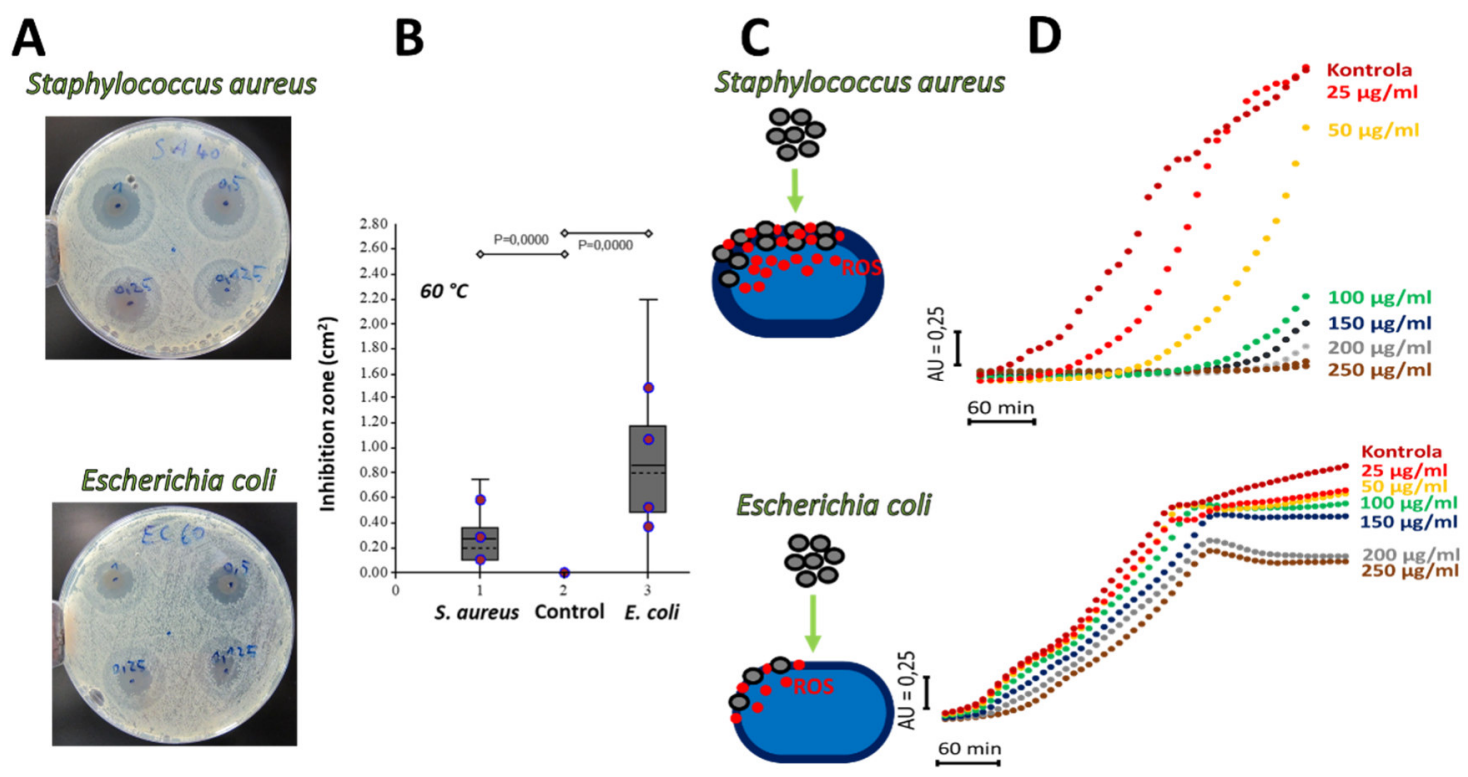

Figure $3(\mathrm{~A})$ Agar diffusion assay with inhibition zones obtained. The schema shows the AgNPs concentrations used in the Petri dish. (B) Box plots comparing the area of inhibition zone of AgNPs to E. coli and $S$. aureus. The purified sterilised water was used as a control. 4 different amounts of AgNPs of every sort was pipetted to a Petri dish $(200,150,100,50 \mu \mathrm{g})$. The inhibition area was calculated from the picture by using laboratory information system. (C) Assumed differential effect of AgNPs on $\mathrm{G}^{+}$and $\mathrm{G}^{-}$bacteria.

More AgNPs bind to the wider cell wall of the bacterium leading to higher ROS production. $\mathrm{G}^{+}$bacterial cell is inhibited faster than $\mathrm{G}^{-}$cell. (D) Confirming the supposed fact by inhibiting bacterial growth curves. At the same AgNPs concentrations used, there was a significant difference in the effect on both $\mathrm{G}^{+}$and $\mathrm{G}^{-}$bacteria [14].

\section{CONCLUSION}

Green synthesized silver nanoparticles provide the possibility to effectively combat bacterial resistance. Bound biomolecules from the plant extract of $S$. officinalis support the antibacterial effect of AgNPs alone. $S$. officinalis is rich in secondary metabolites of phenolic nature; it contains flavonoids in relatively high concentrations, which play an important role in the process of green synthesis and subsequent antibacterial activity of prepared AgNPs. We have prepared AgNPs using green synthesis and have demonstrated their great antibacterial effect both on $\mathrm{G}^{+}$and $\mathrm{G}^{-}$bacteria. In our other experiments, the AgNPs activity on other 
bacterial cells and on penicillin-resistant bacteria will be tested. AgNPs can be used to treat bacterial infections in synergy with various antibiotics.

\section{ACKNOWLEDGEMENTS}

\section{The work was carried out with the support of the H2020 CA COST Action CA15114, INTER-COST LTC18002.}

\section{REFERENCES}

[1] SHARIFI-RAD, M., OZCELIK, B., ALTIN, G., DASKAYA-DIKMEN, C., MARTORELL, M., RAMIREZ-ALARCON, K., ALARCON-ZAPATA, P., MORAIS-BRAGA, M. F. B., CARNEIRO, J. N. P., LEAL, A., COUTINHO, H. D. M., GYAWALI, R., TAHERGORABI, R., IBRAHIM, S. A., SAHRIFI-RAD, R., SHAROPOV, F., SALEHI, B., CONTRERAS, M. D., SEGURA-CARRETERO, A., SEN, S., ACHARYA, K., SHARIFI-RAD, J. Salvia spp. plantsfrom farm to food applications and phytopharmacotherapy. Trends Food Sci. Technol., 2018, vol. 80, no. pp. 242263.

[2] JAKOVLJEVIC, M., JOKIC, S., MOLNAR, M., JASIC, M., BABIC, J., JUKIC, H., BANJARI, I. Bioactive Profile of Various Salvia officinalis L. Preparations. Plants-Basel, 2019, vol. 8, no. 3, pp. 30.

[3] MOGHADAM, S. B., MASOUDI, R., MONSEFI, M. Salvia officinalis Induces Apoptosis in Mammary Carcinoma Cells Through Alteration of Bax to Bcl-2 Ratio. Iranian J. Sci. Tech., 2018, vol. 42, no. A1, pp. 297-303.

[4] ER, M., TUGAY, O., OZCAN, M. M., ULUKUS, D., AL-JUHAIMI, F. Biochemical properties of some Salvia L. species. Environ. Monit. Assess., 2013, vol. 185, no. 6, pp. 5193-5198.

[5] WANG, M. F., LI, J. G., RANGARAJAN, M., SHAO, Y., LAVOIE, E. J., HUANG, T. C., HO, C. T. Antioxidative phenolic compounds from sage (Salvia officinalis). J. Agric. Food Chem., 1998, vol. 46, no. 12, pp. 4869-4873.

[6] LU, Y. R., FOO, L. Y. Antioxidant activities of polyphenols from sage (Salvia officinalis). Food Chem., 2001, vol. 75, no. 2, pp. 197-202.

[7] BOZIN, B., MLMICA-DUKIC, N., SAMOJLIK, I., JOVIN, E. Antimicrobial and antioxidant properties of rosemary and sage (Rosmarinus officinalis L. and Salvia officinalis L., lamiaceae) essential oils. J. Agri. Food Chem., 2007, vol. 55, no. 19, pp. 7879-7885.

[8] BOZIN, B., MLMICA-DUKIC, N., SAMOJLIK, I., JOVIN, E. Antimicrobial and antioxidant properties of rosemary and sage (Rosmarinus officinalis L. and Salvia officinalis L., lamiaceae) essential oils. Journal of Agricultural and Food Chemistry, 2007, vol. 55, no. 19, pp. 7879-7885.

[9] PETERSEN, M., SIMMONDS, M. S. J. Molecules of interest - Rosmarinic acid. Phytochemistry, 2003, vol. 62, no. 2, pp. 121-125.

[10] BAHARARA, J., RAMEZANI, T., MOUSAVI, M., ASADI-SAMANI, M. Antioxidant and anti-inflammatory activity of green synthesized silver nanoparticles using Salvia officinalis extract. Annals of Tropical Medicine and Public Health, 2017, vol. 10, no. 5, pp. 1265-1270.

[11] HUSSAIN, M., RAJA, N. I., IQBAL, M., ASLAM, S. Applications of Plant Flavonoids in the Green Synthesis of Colloidal Silver Nanoparticles and Impacts on Human Health. Iranian Journal of Science and Technology Transaction a-Science, 2019, vol. 43, no. A3, pp. 1381-1392.

[12] SHARMA, V. K., YNGARD, R. A., LIN, Y. Silver nanoparticles: Green synthesis and their antimicrobial activities. Advances in Colloid and Interface Science, 2009, vol. 145, no. 1-2, pp. 83-96.

[13] PANACEK, A., KVITEK, L., SMEKALOVA, M., VECEROVA, R., KOLAR, M., RODEROVA, M., DYCKA, F., SEBELA, M., PRUCEK, R., TOMANEC, O., ZBORIL, R. Bacterial resistance to silver nanoparticles and how to overcome it. Nature Nanotechnology, 2018, vol. 13, no. 1, pp. 65-71.

[14] MARAMBIO-JONES, C., HOEK, E. M. V. A review of the antibacterial effects of silver nanomaterials and potential implications for human health and the environment. Journal of Nanoparticle Research, 2010, vol. 12, no. 5, pp. 1531-1551. 